\title{
Weshalb Schweizer Ärzte Bundesparlamentariern schreiben
}

\author{
Jean-Jacques Fasnacht \\ Dr. med., Präsident IPPNW Schweiz
}

\author{
Alle in der World Medical Association (WMA) organisierten nationalen Ärztegesell- \\ schaften haben sich verpflichtet, bei ihren jeweiligen Regierungen auf den Bann \\ und die Eliminierung von Atomwaffen einzuwirken. Noch hat die Schweiz den \\ Atomwaffenverbotsvertrag jedoch weder unterzeichnet noch ratifiziert.
} Als Ärztinnen und Ärzte sind wir verpflichtet, uns voll
und ganz für das Wohl und die Gesundheit der Bevöl-
kerung einzusetzen. Dabei geht es nicht nur um das
Heilen von Leiden, sondern vor allem auch um das
Verhindern von möglichen gesundheitlichen Schäden
und Risiken.
Unsere grosse Sorge gilt deshalb auch dem möglichen
Einsatz von Atomwaffen. Ein neues globales nukleares
Wettrüsten findet statt [1]. Die mögliche nukleare
Deeskalation auf der koreanischen Halbinsel ist nach
wie vor nicht in Stein gemeisselt und es droht, nach
der Kündigung des Atomwaffenvertrags mit dem Iran
durch die USA, die nukleare Eskalation im Nahen Osten.
Angesichts der Evidenz der katastrophalen Auswirkun-
gen von Nuklearwaffen und auf Grund unserer ethi-
schen Verpflichtung haben sich sämtliche in der WMA
(World Medical Association) organisierten nationalen

\section{WMA Council Resolution}

\section{on the Prohibition of Nuclear Weapons}

Adopted by the 209th Session of the Council, Riga, April 2018

The duties of physicians are to preserve life and safeguard the health of the patient and to dedicate themselves to the service of humanity.

Concerned about current global discussions on nuclear proliferation and given the catastrophic consequences of these weapons on human health and the environment, the World Medical Association (WMA) and its Constituent Members consider that they have a responsibility to work for the elimination of nuclear weapons worldwide.

The WMA is deeply concerned by plans to retain indefinitely and modernize nuclear arsenals; the absence of progress in nuclear disarmament by nuclear-armed states; and the growing threat of nuclear war.

The WMA welcomes the Treaty on the Prohibition of Nuclear Weapons, and joins with others in the international community, including the Red Cross and Red Crescent movement, International Physicians for the Prevention of Nuclear War, the International Campaign to Abolish Nuclear Weapons, and a large majority of UN member states. Consistent with our mission as physicians, the WMA calls on all states to promptly sign, ratify or accede to, and faithfully implement the Treaty on the Prohibition of Nuclear Weapons;

Emphasizing the devastating long-term health consequences, the WMA and its Constituent Members urge governments to work immediately to prohibit and eliminate nuclear weapons.

Ärztegesellschaften, zu denen die FMH Schweiz gehört, verpflichtet, bei ihren jeweiligen Regierungen auf den Bann und die Eliminierung von Atomwaffen einzuwirken [2].

Seit dem 20. September 2017 liegt ein Atomwaffenverbotsvertrag («Treaty on the Prohibition of Nuclear Weapons / TPNW») zur Unterschrift bereit, auf den sich 122 Nationen - unter ihnen auch die Schweiz - am 7. Juli 2017 formell geeinigt haben. Damit soll ein klares Signal gesetzt und ein wichtiger Schritt hin zur vollkommenen Ächtung der nuklearen Massenvernichtungswaffen getan werden.

In Ihrer Resolution vom 28.4.2018 fordert die WMA nun alle Staaten explizit dazu auf, den TPNW umgehend zu unterzeichnen und das Verbot von Atomwaffen umzusetzen [3].

Noch hat die Schweiz diesen Vertrag jedoch weder unterzeichnet noch ratifiziert. Aus diesem Grunde haben wir Schweizer Medizinerinnen und Mediziner in unserem Schreiben die Parlamentarier gebeten, dabei mitzuhelfen, dass diese weltumspannende Vereinbarung auch von der Schweiz unterzeichnet wird. Der Schweiz, unserer Schweiz, die für ihren Einsatz für humanitäre Anliegen und Frieden weltweit geachtet und geschätzt wird.

Anfangs Juni 2018 hat dann eine Mehrheit des Nationalrats einer Motion zugestimmt, welche die Unterzeichnung des Vertrags fordert. Der Ständerat wird nach den Sommerferien darüber befinden.

\section{Literatur}

1 Bittner J. Atomkrieg: Die Eskalation. Zeit 14. Februar 2018 unter https://www.zeit.de/2018/08/atomkrieg-ruestungsindustrieatomwaffen-usa-russland

2 Fasnacht J-J. Die Elimination von Atomwaffen. Auch eine ärztliche Verpflichtung. Schweiz Ärzteztg 2017;89(36):1136-7, auch unter https://saez.ch/de/article/doi/saez.2017.05930/

3 WMA Council resolution on the prohibition of nuclear weapons. 28. April 2018 unter https://www.wma.net/policies-post/councilresolution-on-the-prohibition-of-nuclear-weapons/ 